\title{
Utilization of volatile fatty acids and glucose for protein deposition in lambs*
}

\author{
By B. ESKELAND†, W. H. PFANDER AND R. L. PRESTON+ \\ Department of Animal Husbandry, University of Missouri, \\ Columbia, Missouri, USA
}

(Received I9 Fanuary 1972-Accepted 20 October 1972)

\begin{abstract}
I. Glucose, and acetic, propionic and butyric acids, the major energy sources available to ruminants, have been comparatively evaluated as energy sources for growth in lambs. The energy sources were administered intravenously at 2.092 and $2.510 \mathrm{MJ}$ metabolizable energy per $24 \mathrm{~h}$ for periods of $9-\mathbf{2} 2 \mathrm{~d}$. Nitrogen was given in excess of requirement so that growth rate was limited by energy, as indicated by the increased $\mathrm{N}$ retention after intravenous administration of energy.

2. The $\mathrm{N}$-balance results from the trials showed that propionic acid promoted a significantly $\left(P<O^{\circ} \circ \mathrm{I}\right)$ higher $N$ retention than acetic acid. In some of the experiments there were no significant differences between propionic and butyric acids, and in others, no significant differences between acetic and butyric acids. Compared with isoenergetic glucose infusion, all volatile fatty acids were less efficiently utilized than glucose. The mean values for $\mathrm{N}$ balance $(\mathrm{g} / \mathrm{d}$ ) were $2.3 \mathrm{r}$ during control infusion, $6.53,5 \cdot 7 \mathrm{r}, 5.48$ and 4.59 during glucose, propionate, butyrate and acetate infusions, respectively.

3. All energy sources reduced the faecal $\mathrm{N}$ excretion significantly. The greatest reduction was observed during butyrate treatment. The mean values for faccal $\mathrm{N}$ excretion $(\mathrm{g} / \mathrm{d})$ were $4 \cdot 24$ for control, 4.00 for acetate, 3.89 for propionate, 3.83 for glucose, and 3.76 for butyrate infusion. The reduced faecal $N$ excretion after butyrate infusion partly accounts for the increased $\mathrm{N}$ retention with that treatment.
\end{abstract}

Differing efficiencies of utilization of acetic, propionic and butyric acids in both fasting and fattening sheep have been demonstrated by Blaxter and his colleagues (Armstrong \& Blaxter, 1957 $a, b$; Armstrong, Blaxter, Graham \& Wainman, 1958). In growing lambs, Bentley, Johnson, Royal, Deatherage, Kunkle, Tyznik \& Bell (1956), Hovell (1964) and Elliot, Hogue, Myers \& Loosli (I965) found no differences between the salts of the volatile fatty acids (VFA) in their effects on body gain and carcass composition. In a series of studies, Ørskov \& Allen (I966a,b,c) and Ørskov, Hovell \& Allen (I966) found no significant differences among the three major VFA in ability to promote growth in lambs. In a nitrogen balance study Ørskov \& Allen (I966c) observed a trend towards acetate being more efficiently used than propionate or butyrate, and the same non-significant trend was previously reported by Rook, Balch, Campling $\&$ Fisher $\left(196_{3}\right)$ with cattle.

The experiments reported herein were started in 1967 with the object of evaluating glucose, acetic, propionic and butyric acids as sources of encrgy for protein deposition when given in continuous intravenous infusions on an isoenergetic basis.

* Contribution from the Missouri Agricultural Experiment Station. Journal Series No. 6278. Approved by the Director.

$\uparrow$ Present address: Agricultural College of Norway, 1432 Vollebekk, Norway.

I Present address: Ohio Agricultural Research and Development Center, Wooster, Ohio, USA. 
EXPERIMEN TAL

\section{Animals and their management}

Two to four wether lambs, 4-5 months of age, were used in each of these studies. For each experiment, lambs were selected that were uniform as far as weight and breeding were concerned. The lambs were crossbred (Hampshire $\times$ Dorset), and their weights ranged from 24.5 to $35 \mathrm{~kg}$.

For I week before their confinement in metabolism stalls, the lambs were fed on the experimental diet at the same level as during later infusion periods. Another week was allowed for the animals to adapt to the metabolism stalls; during this period the jugular vein was catheterized and prepared for infusion periods of 40-60 d.

The jugular vein was entered at the anterior triangle with a $650 \mathrm{~mm}, \mathrm{x}_{4}$ gauge, thin-walled hypodermic needle. A I.5 m polyethylene tube (P.E. I00) (Clay Adams, Inc., New York, NY) was pushed approximately $300 \mathrm{~mm}$ to the level of the superior vena cava. When the catheter was in place, the needle was removed. Elastic rubber tubing, $400 \mathrm{~mm}$ long, was fitted outside the polyethylene tubing, from the insertion point on the jugular vein, to prevent the polyethylene tubing from breaking or being displaced, or both. Two or three stitches were used to secure the tubing to the skin at the insertion point. The tubing was attached to the wool along the neck with umbilical tape. The skin stitches were replaced once every 3 weeks. Catheters were kept functional for periods of $90-100 \mathrm{~d}$ with no infection or malfunction. No noticeable changes in appetite or body temperature were detected after the catheters were placed. A female Luer-slip adapter at the distal end of the catheter connected it to the microbilateral roller pump (Holter Co., Bridgeport, Pa) which was mounted on a frame above and somewhat behind the lambs. Each pump was connected to solutions that supplied two sheep. The VFA were diluted with autoclaved demineralized water, neutralized with $\mathrm{NaOH}$, and adjusted to $\mathrm{pH} 7 \cdot 2-7 \cdot 4$. Glucose was dissolved in demineralized water, diluted to volume and autoclaved. Fresh solutions were connected to the pumps daily. The energy sources used in this study did not affect the general appearance of the lambs.

The metabolism stalls were kept in a room where a temperature of $20-25^{\circ}$ was maintained. The lambs were given the ration twice daily at slightly above maintenance level of digestible energy (DE) calculated by the formula $586 \mathrm{~kJ}$ (140 kcal) $\times W_{\mathrm{kg}}^{0.75}$. Quantitative collections of urine and faeces were made daily from the 5 th day onward during each infusion period.

Expt I was conducted during September, October and early November 1967, and two lambs, both weighing $33 \mathrm{~kg}$, were used. Diet 3 was offered at $6 \%$ of $W_{\mathrm{kg}}^{0.75}$, supplying $8.870 \mathrm{MJ}$ DE and $18 \mathrm{~g} \mathrm{~N} / \mathrm{d}$. The experiment was composed of five $10 \mathrm{~d}$ infusion periods, and the daily infusion rate into the jugular vein was 21 . During the control period the lambs were infused with the same volume of physiological saline solution.

Expt 2 was conducted during the months of December 1967 , and January I 968 , with two lambs having an average body-weight of $28 \mathrm{~kg}(27 \cdot 3$ and 28.8$)$. They were offered diet 4 at $\mathrm{I} \cdot 2 \times$ estimated maintenance level of $\mathrm{DE}(8 \cdot 368 \mathrm{MJ} \mathrm{DE} / \mathrm{d})$, and $\mathrm{N}$ at 
Table I. Infusion sequences in Expts I, 2, 3 and 4 for periods $\mathrm{I}-\mathrm{VI}$

\begin{tabular}{|c|c|c|c|c|c|c|}
\hline \multirow[b]{2}{*}{ Expt no. } & \multirow[b]{2}{*}{ Lamb no. } & \multicolumn{5}{|c|}{ Substrate infused } \\
\hline & & Saline & Glucose & Acetate & Propionate & Butyrate \\
\hline $\mathrm{r}$ & $\begin{array}{l}3 \mathrm{I} 80 \\
3 \mathrm{I} 9 \mathrm{I}\end{array}$ & $\begin{array}{l}\text { I } \\
\text { I }\end{array}$ & II & $\begin{array}{l}\text { IV } \\
\text { III }\end{array}$ & $\begin{array}{l}\text { III } \\
\text { IV }\end{array}$ & $\begin{array}{l}\text { V } \\
\text { II }\end{array}$ \\
\hline 2 & $\begin{array}{l}3222 \\
3205\end{array}$ & $\begin{array}{l}I \text { and } V I \\
I \text { and } I V\end{array}$ & $\begin{array}{l}\text { II } \\
\text { VI }\end{array}$ & $\begin{array}{l}\text { IV } \\
\text { III }\end{array}$ & $\underset{\mathrm{V}}{\mathrm{III}}$ & $\begin{array}{l}\text { V } \\
\text { II }\end{array}$ \\
\hline 3 & $\begin{array}{l}330 \mathrm{r} \\
3356\end{array}$ & $\begin{array}{l}\text { I } \\
\text { I }\end{array}$ & $\begin{array}{l}\text { II } \\
\text { II }\end{array}$ & $\begin{array}{l}\text { IV } \\
\text { IV }\end{array}$ & $\begin{array}{l}\text { III } \\
\text { III }\end{array}$ & $\begin{array}{l}\mathrm{V} \\
\mathrm{V}\end{array}$ \\
\hline 4 & $\left.\begin{array}{l}3635 \\
3682\end{array}\right\}$ & $\mathrm{I}$ and $\mathrm{VI}$ & II & IV & $\mathrm{V}$ & III \\
\hline & $\left.\begin{array}{l}3756 \\
3693\end{array}\right\}$ & I and VI & $\mathrm{V}$ & III & II & IV \\
\hline
\end{tabular}

$20 \mathrm{~g} / \mathrm{d}$. Acetate, propionate, butyrate and glucose were infused intravenously at $2 \cdot 092 \mathrm{MJ} / \mathrm{d}$ in 21 aqueous solutions. The length of each of the six infusion periods was ro d. A control period was repeated at the end of each experiment.

Expt 3 was carried out during late March, April and early May I968, with two $30 \mathrm{~kg}$ lambs. This trial differed from the two preceding experiments in that during the control (saline) period the lambs were given a different basal diet (diet 5) to supply an amount of $\mathrm{DE}$ isoenergetic with that given in the periods in which the lambs received the intravenous infusion of the different energy sources. During the control period $10.878 \mathrm{MJ} \mathrm{DE}$ were supplied per $\mathrm{d}$ in diet 5 , and during the energy infusion periods the lambs received 8.368 $\mathrm{MJ}$ from diet 4. Both rations supplied $20 \mathrm{~g} \mathrm{~N}$ daily. Glucose, acetate, propionate or butyrate was infused at the rate of $2.5 \mathrm{I} 2 \mathrm{MJ} / \mathrm{d}$. The duration of each of the five infusion periods was $12 \mathrm{~d}$.

Expt 4 was conducted during June and July I968, with four lambs, 5 months old, ranging in body-weight between 33.5 and $35^{\circ} \circ \mathrm{kg}$. Diet 4 was offered at the estimated maintenance level of $\mathrm{DE}$, supplying $8.368 \mathrm{MJ} / \mathrm{d}$, and $2.510 \mathrm{MJ}$ of the respective energy sources were administered intravenously, representing $23 \%$ of total energy DE intake. The basal ration supplied $20 \mathrm{~g} \mathrm{~N}$ daily. The volume infused per $24 \mathrm{~h}$ was reduced to $\mathrm{I} \cdot \mathrm{O} 1$. Two sheep received two sequences of six infusion periods, each period lasting $8 \mathrm{~d}$. The saline infusion was repeated after these periods. The infusion sequence used in Expts $\mathrm{I}-4$ is shown in Table $\mathrm{I}$.

Expt 5 was carried out during December 1968 and January 1969. Four lambs ranging in body-weight between 24.5 and $26.0 \mathrm{~kg}$ were used in this experiment. Diet 6 was offered at $5.63 \%$ of $W_{\mathrm{kg}}^{0 \cdot 75}$, supplying $6.878 \mathrm{MJ} \mathrm{DE}\left(\mathrm{I} \cdot{ }^{\circ} 5 \times\right.$ estimated maintenance level) and $20 \mathrm{~g} \mathrm{~N}$ daily. The experiment followed a $4 \times 4$ Latin square design, preceded by a saline (control) infusion period for all lambs in order to establish their $\mathrm{N}$ balance before infusion of the different energy sources. The energy infusion represented $24 \%$ of the total energy supplied, and the length of each infusion period was ro d.

We had assumed, and our results from Expts 2 and 4 showed, that on such a low 
Table 2. Gross, chemical and energy compositions of the diets*

\begin{tabular}{|c|c|c|c|c|}
\hline & Diet 3 & Diet 4 & Diet 5 & Diet 6 \\
\hline Ingredient & \multicolumn{4}{|c|}{ Gross composition $(\mathrm{g} / \mathrm{kg})$} \\
\hline Cottonseed hulls & $350^{\circ} 0$ & $350 \cdot 0$ & $350^{\circ} \cdot 0$ & $350 \cdot 0$ \\
\hline Molasses, cane & $100 \cdot 0$ & $100 \cdot 0$ & $100 \cdot 0$ & $100 \cdot 0$ \\
\hline Maize, cracked & $320 \cdot 0$ & $255^{\circ} \circ$ & 363.0 & $x 86 \cdot 0$ \\
\hline Soya-bean meal, $44 \%$ & $207 \cdot 5$ & $273 \cdot 0$ & 164.0 & $340 \cdot 0$ \\
\hline Limestone & $7 \cdot 5$ & $7 \cdot 0$ & $7 \cdot 5$ & $9 \cdot 0$ \\
\hline Dicalcium phosphate & 一 & - & 0.5 & - \\
\hline Cobalt, iodized salt $†$ & $5 \cdot 0$ & $5 \cdot 0$ & $5 \cdot 0$ & $5 * 0$ \\
\hline Vitamin premix & 10.0 & 10.0 & 10.0 & 10.0 \\
\hline Component & \multicolumn{4}{|c|}{ Chemical and energy composition } \\
\hline Crude protein $(\mathrm{g} / \mathrm{kg})$ & $140^{\circ} 0$ & I $64^{-4}$ & $125 \cdot 0$ & I98.0 \\
\hline Digestible energy (MJ/kg) & II.088 & I I.004 & $I I \cdot I 29$ & 10.910 \\
\hline Neutral detergent fibre $(\mathrm{g} / \mathrm{kg}) \ddagger$ & - & $469 \cdot 0$ & - & 436.0 \\
\hline Acid detergent fibre $(\mathrm{g} / \mathrm{kg})\rfloor$ & - & $267 \cdot 0$ & - & $249 \cdot 0$ \\
\hline Lignin $(\mathrm{g} / \mathrm{kg})$. & 一 & $53 \cdot 0$ & - & $5 I \cdot 0$ \\
\hline Cellulose $(\mathrm{g} / \mathrm{kg}) \ddagger$ & - & $216 \cdot 0$ & - & $199 \cdot 0$ \\
\hline Fibre $(\mathrm{g} / \mathrm{kg})$ & - & $1>8 \cdot 2$ & - & $127 \cdot 1$ \\
\hline Calcium $(\mathrm{g} / \mathrm{kg})$ & $4 \cdot 7$ & $5 \cdot 1$ & $4 \cdot 8$ & $6 \cdot 4$ \\
\hline Phosphorus $(\mathrm{g} / \mathrm{kg})$ & $2 \cdot 8$ & $2 \cdot 8$ & $2 \cdot 9$ & $3 \cdot 4$ \\
\hline
\end{tabular}

* Diet 3 was used in Expt 1 , diet 4 was used in Expts 2, 3 and 4 , diet 5 was used in Expt 3 in the control period, and diet 6 was used in Expt 5 .

+ Iodized salt containing $225 \mathrm{mg} \mathrm{CoCl}_{2} .6 \mathrm{H}_{2} \mathrm{O} / \mathrm{kg}$.

\& Van Soest fibre analysis (Van Soest, 1967).

energy intake the lambs had the same growth potential at the end of the experiment as at the beginning, and this was the reason for not repeating the control treatment.

\section{Diets}

The ingredients and chemical compositions of the experimental diets are given in Table 2.

\section{Statistical analysis}

In Expts I, 3 and 5 the interaction of infusion $\times$ sheep $\times d$ was used as the experimental error ( 16 df in Expts $I$ and 3, 60 df in Expt 5). The statistical model was:

$X_{i j k}=u+E_{i}+S_{j}+D_{k}+E S_{i j}+E D_{i k}+S D_{j k}+e_{i j k}$, where $X_{i j k}=$ observed value, $u=$ the common mean of all samples, $E_{i}=$ the effect of energy sources, with $i$ being the number of the source, $S_{j}=$ the effect of sheep, with $j$ being the number of the sheep, $D_{k}=$ the effect of days of collection, with $k$ being the number of the day. $E S_{i j}, E D_{i k}$ and $S D_{j k}$ represent interactions.

In Expts 2 and 4 the day effect was not partitioned. The statistical model was:

$$
\mathrm{K}_{i j k}=u+E_{i}+S_{j}+E S_{i j}+e_{i j k} \text {. }
$$

This model is the same as above except that it was assumed that there were no consistent differences between days.

In Expts $\mathrm{I}, 3$ and 5 the infusion $\times$ sheep interaction was tested against the three factor interaction and was not significant for urinary $\mathrm{N}(F$ ratio 0.6 to $\mathrm{I} \cdot 3)$, faecal $\mathrm{N}$ 
Table 3. Daily urinary nitrogen, faecal $N$ and $N$ balance of the lambs during periods $I I$ to $V$ in Expt 5 (all values in $g / d$ )

$\begin{array}{lrrrr}\quad \text { Period } & \text { II } & \text { III } & \text { IV } & \text { V } \\ \text { Urinary N } & 10.24 & 10.46 & 9.96 & 10 \cdot 10 \\ \text { Faecal N } & 3.54 & 3.63 & 3.74 & 3.64 \\ \text { N balance } & 5.22 & 4.91 & 5.30 & 5.26\end{array}$

( $F$ ratio 0.9 to $\mathrm{I}^{\cdot} 4$ ) and $\mathrm{N}$ balance ( $F$ ratio 0.7 to $\left.{ }^{\cdot} \cdot 7\right)$. In Expt 2 the infusion $\times$ sheep interaction was significant for urinary $\mathrm{N}$ and $\mathrm{N}$ balance. It might therefore be better to use this interaction as the error term, but the differences between infusions were so large that the conclusions would be unaltered. The infusion $\times$ sheep interaction was not significant in Expt 4.

Saline was given in the first period and also in the last period in some experiments. The validity of comparisons between saline and the energy-source infusions may therefore be questioned. The results of Expt 5 are reassuring since there were no significant differences between periods II to $\mathrm{V}$ as shown in Table 3 for urinary $\mathrm{N}$ excretion, faecal $\mathrm{N}$ excretion and $\mathrm{N}$ balance.

In Expts 2 and 4 the mean N retention of $\mathrm{I} \cdot 35 \mathrm{v} . \mathrm{I} \cdot 20 \mathrm{~g} / \mathrm{d}$ in periods I and VI (I and IV for one sheep) was recorded for the six sheep receiving saline, respectively, and indicate no significant effect of time in these experiments, so apparently the lambs had the same growth potential at the end of the experiment as at the beginning.

RESULTS

\section{Uninary $N$ excretion}

The effects of the intravenous infusion of saline, glucose, acetate, propionate and butyrate are presented in Table 4 . There were significant differences among the treatments in relation to urinary $\mathrm{N}$ excretion $(P<0.0 \mathrm{I})$. In all experiments glucose infusion gave a significant reduction in urinary $\mathrm{N}$ excretion and the reduction was greater than that found for the other energy sources. In all but Expt 5 , glucose infusion resulted in a urinary $\mathrm{N}$ excretion that was significantly $(P<0 \cdot 0 \mathrm{I})$ less than that of propionate. Propionate infusion always decreased the urinary $\mathrm{N}$ output morc than butyrate treatment, but only in Expt 5 were the differences between these two energy sources significant $(P<\mathrm{O} \cdot 0 \mathrm{I})$.

Butyrate treatment lowered the $\mathrm{N}$ excretion more than acetate infusion, except in Expt 5, where no significant differences were attained. Acetate infusion compared with saline infusion lowered the urinary $\mathrm{N}$ excretion, but this effect was not significant in Expts I and 3. In Expt 3, where the control animals were given additional dietary energy, both acetate and butyrate infusions increased the urinary $N$ excretion compared with that obtained on saline. 
Table 4. Effect of intravenous infusions of different energy sources* on mean $\dagger$ urinary nitrogen, faecal $N$ and $N$ balance of lambs in all experiments (all values expressed in $g / d$ )

\begin{tabular}{|c|c|c|c|c|c|c|}
\hline & & & strate infu & & & \\
\hline & Saline & Glucose & Acetate & Propionate & Butyrate & SEM \\
\hline $\begin{array}{l}\text { Expt I: } \\
\text { Urinary } N \text { excretion } \\
\text { Faecal } N \text { excretion } \\
\mathrm{N} \text { balance }\end{array}$ & $\begin{array}{l}9 \cdot 65^{a \ddagger} \\
4 \cdot 65^{a} \\
3 \cdot 70^{a}\end{array}$ & $\begin{array}{l}6 \cdot 85^{b} \\
3 \cdot 97^{b} \\
7 \cdot 18^{b}\end{array}$ & $\begin{array}{l}9 \cdot 38^{a} \\
4 \cdot 20^{b} \\
4 \cdot 42^{c}\end{array}$ & $\begin{array}{l}8 \cdot 39^{c} \\
3 \cdot 91^{b} \\
5 \cdot 70^{d}\end{array}$ & $\begin{array}{l}8 \cdot 4 \mathrm{I}^{e} \\
3 \cdot 83^{b} \\
5 \cdot 76^{d}\end{array}$ & $\begin{array}{l}0 . I_{4} \\
0.13 \\
0.09\end{array}$ \\
\hline $\begin{array}{l}\text { Expt 2: } \\
\text { Urinary } N \text { excretion } \\
\text { Faecal } N \text { excretion } \\
N \text { balance }\end{array}$ & $\begin{array}{r}14 \cdot 23^{a} \\
4 \cdot 19^{a} \\
1 \cdot 58^{a}\end{array}$ & $\begin{array}{l}9^{\cdot} 31^{b} \\
4^{\circ} \cdot 4^{a b} \\
6 \cdot 55^{b}\end{array}$ & $\begin{array}{r}\text { I I. } 13^{c} \\
4 \cdot 24^{a} \\
4 \cdot 63^{c}\end{array}$ & $\begin{array}{l}9 \cdot 89^{d} \\
4 \cdot 15^{a} \\
5 \cdot 96^{d}\end{array}$ & $\begin{array}{r}10 \cdot 25^{a} \\
3.95^{a} \\
5 \cdot 80^{a}\end{array}$ & $\begin{array}{l}0.10 \\
0.07 \\
0.10\end{array}$ \\
\hline $\begin{array}{l}\text { Expt } 3: \\
\text { Urinary } N \text { excretion } \\
\text { Faecal } N \text { excretion } \\
\mathrm{N} \text { balance }\end{array}$ & $\begin{array}{r}\text { Io. } 88^{\alpha} \\
4 \cdot 35^{\alpha} \\
4 \cdot 77^{a}\end{array}$ & $\begin{array}{l}9 \cdot 42^{b} \\
4 \cdot 30^{a c} \\
6 \cdot 28^{b}\end{array}$ & $\begin{array}{r}\mathbf{1} \cdot 45^{c} \\
4 \cdot 57^{a} \\
3 \cdot 98^{c}\end{array}$ & $\begin{array}{l}10 \cdot 46^{a} \\
4^{\circ} \cdot 4^{b c} \\
5^{\cdot} 5^{d}\end{array}$ & $\begin{array}{l}\text { I I } 2 \mathbf{I}^{a c} \\
3 \cdot 89^{b} \\
4 \cdot 90^{a}\end{array}$ & $\begin{array}{l}0.25 \\
0.10 \\
0.14\end{array}$ \\
\hline $\begin{array}{l}\text { Expt } 4: \\
\text { Urinary N excretion } \\
\text { Faecal N excretion } \\
\text { N balance }\end{array}$ & $\begin{array}{l}\text { I } \cdot 65^{a} \\
4 \cdot 22^{a} \\
I \cdot 13^{a}\end{array}$ & $\begin{array}{l}9 \cdot 84^{b} \\
3 \cdot 64^{b} \\
6 \cdot 52^{b}\end{array}$ & $\begin{array}{l}x+47^{\circ} \\
3 \cdot 79^{b} \\
4 \cdot 74^{\circ}\end{array}$ & $\begin{array}{r}10 \cdot 50^{d} \\
3 \cdot 83^{b} \\
5 \cdot 67^{d}\end{array}$ & $\begin{array}{r}10 \cdot 67^{d} \\
3 \cdot 72^{b} \\
5 \cdot 6 I^{d}\end{array}$ & $\begin{array}{l}0.15 \\
0.09 \\
0.15\end{array}$ \\
\hline $\begin{array}{l}\text { Expt } 5: \\
\text { Urinary } N \text { excretion } \\
\text { Faecal } N \text { excretion } \\
\mathrm{N} \text { balance }\end{array}$ & $\begin{array}{l}12 \cdot 26^{a} \\
3 \cdot 90^{a} \\
2 \cdot 84^{a}\end{array}$ & $\begin{array}{l}9 \cdot 57^{b} \\
3 \cdot 57^{b} \\
5 \cdot 86^{b}\end{array}$ & $\begin{array}{l}10 \cdot 66^{c} \\
3 \cdot 78^{a b} \\
4 \cdot 5^{c}\end{array}$ & $\begin{array}{l}9 \cdot 84^{b} \\
3 \cdot 66^{a b} \\
5 \cdot 50^{b}\end{array}$ & $\begin{array}{r}10 \cdot 69^{c} \\
3 \cdot 56^{b} \\
4 \cdot 75^{c}\end{array}$ & $\begin{array}{l}0.15 \\
0.10 \\
0.14\end{array}$ \\
\hline
\end{tabular}

\section{Faecal $N$ excretion}

As indicated in Table 4, all energy infusions generally lowered the faecal $\mathrm{N}$ output, except in Expts 2 and 3 when acetate infusion increased the faecal $\mathrm{N}$ excretion - but the values were not significantly different from control values. Butyrate infusion decreased faecal $\mathrm{N}$ excretion significantly in all experiments and the effect of butyrate was greater than that of any other energy source except in Expt 4 when the effect of glucose was greatest. In Expt 2 only butyrate infusion significantly decreased the faecal $\mathrm{N}$ excretion, in Expt 5 butyrate and glucose, in Expt 3 butyrate and propionate, and in Expts I and 4 all energy sources significantly lowered the faecal $\mathrm{N}$ output.

\section{$N$ balance}

The $\mathrm{N}$-balance results from all experiments are given in Table 4 . The same trend was generally observed in all experiments in that more $\mathrm{N}$ was retained during glucose infusion than during the infusion of any of the other energy sources. In Expt I the $\mathrm{N}$ balance was slightly higher after butyrate than after propionate infusion. In Expts $\mathrm{r}, 2$ and 4 there were no significant differences between propionate and butyrate treatments in respect of $\mathrm{N}$ retention. The high $\mathrm{N}$-balance response after butyrate was partly due to reduced faecal $\mathrm{N}$ output for that treatment. In Expt 3 , during the control 
(saline) period when the lambs were given a different basal diet suppling an isoenergetic amount of $\mathrm{DE}$ with periods in which the lambs received the intravenous infusion of the different energy sources, acetate significantly lowered the $\mathrm{N}$ balance compared with control, whereas glucose and propionate infusions both significantly increased the $\mathrm{N}$ retention. In Expt 5 there were no significant differences between glucose and propionate infusion and between butyrate and acetate infusion.

When $\mathrm{N}$ retained was expressed as a percentage of $\mathrm{N}$ intake in all experiments, the values increased from $14^{\cdot 6}$ during control period to 33.5 for glucose, $29 \cdot 3$ for propionate, 27.7 for butyrate and $23 \cdot 1$ for acetate infusions.

\section{DISCUSSION}

The increases in $\mathrm{N}$ retention strongly suggest that the intravenous energy sources were used to synthesize protein in the body, and that $\mathrm{N}$ deposition during the control period was limited by energy intake. The effectiveness of the infused energy substrates is then probably related to their ability to provide energy for synthetic reactions and for carbon chains. The response to the different energy sources was similar between experiments, although there were differences in diet, level of feeding, season of year, age and weight of the lambs.

The increased $\mathrm{N}$ retentions for the control group in Expt 3 were due to the basal diet being given at a higher energy level than in the other experiments. In this experiment the DE intake of the control group and of the energy-infused sheep was on an isoenergetic basis.

Our observations do not agree with the results of Rook et al. (1963) who, in one experiment with intraruminal infusion of the VFA in heifers, found that acetate promoted a higher though non-significant $\mathrm{N}$ retention than propionic or butyric acid. In another experiment under similar conditions, they found that butyrate resulted in the highest $\mathrm{N}$ retention, but this effect was also not significant. The result of the first of the above-mentioned experiments, which showed that acetate promoted $\mathrm{N}$ retention more than either propionate or butyrate, agrees with the results of Ørskov \& Allen ( $1966 c$ ), who added salts of acetic and propionic acids to basal rations which were high or low in concentrates. The effect of acetate was greater than that of propionate $(P<0.05)$ on a high-concentrate diet. Their finding that acetate was more efficient than propionate or butyrate in promoting $\mathrm{N}$ retention is difficult to explain. Although the label from ${ }^{14} \mathrm{C}$-labelled acetate has been found in amino acids of milk (Black, Kleiber, Smith \& Stewart, 1957), the findings of Ørskov \& Allen (1966c) and of Rook et al. (1963) provide no information as to whether the increased $N$ retention was an effect of a stimulation of protein synthesis, a sparing effect on protein catabolism, a sparing effect on substances participating in protein synthesis, or an effect of the incorporation of acetate into amino acids. 'The level of feeding in both investigations was rather low, but there may not have been enough digestible protein to support increased $\mathrm{N}$ retention and protein synthesis when additional energy was infused or administered orally. This might especially be true in the work by Rook et al. (1963), as none of the energy infusions significantly increased $\mathrm{N}$ retention. In our experiments, more $\mathrm{N}$ was supplied 
and the experimental animals were younger and also fed at a low level of energy compared with those of Ørskov \& Allen (1966c).

Potter, Purser \& Cline (I968) measured changes in plasma amino acids after shortterm, low-level energy infusions into the carotid artery of mature wethers that had fasted for $24 \mathrm{~h}$. A low index of essential amino acids in the plasma, after injection, was believed to indicate an increased rate of protein synthesis attributable to the energy source. The values recorded after infusion were: glucose 59 , propionate 66 , butyrate 85 , and acetate $9 \circ$. Their technique and the one we are reporting both rank the energy sources in the same order with respect to their ability to promote protein deposition.

Several earlier studies were concerned with the effect of the addition of salts of the major VFA to basal rations on body-weight gain, carcass weight and characteristics (Bentley et al. 1956; Essig, Hatfield \& Johnson, 1959; Hovell, 1964; Thomson, I965; Ørskov \& Allen, 1966a,b, $c$; Ørskov et al. 1966). No significant differences were observed in the efficiencies with which acetate, propionate and butyrate were utilized for body-weight gain, carcass weight and body composition. In their studies the addition of VFA salts at levels not affecting feed intake contributed only a small portion of the total energy supply and may have been too low to show any differences in utilization. In our studies energy infused represented $20-25 \%$ of total $\mathrm{DE}$ ( $30 \%$ of calculated ME) compared with $7-\mathrm{I} 4 \%$ of $\mathrm{ME}$ in those above-mentioned studies. Ørskov \& Allen (Ig66a,b,c) and Ørskov et al. (I966) assumed that acetate supplementation had no effect on the fermentation of the basal diets, but the extent of interconversion of the VFA in the rumen (Leng \& Brett, I966) that may have taken place is unknown. Bergman, Reid, Murray, Brockway \& Whitelaw (1965) have demonstrated that there is little direct interconversion between propionic and acetic acid. They did show that $66 \%$ of butyric acid carbon was in equilibrium with $20 \%$ of acetic acid carbon and that 2-3 g-atom were interconverted each day.

The VFA salts were given only twice daily in the study by Ørskov \& Allen (1966a,c) and Ørskov et al. (1966) and did not represent a continuous source of energy, especially since fast and different rates of absorption of the three major VFA occur (Pfander \& Phillipson, I953).

Ørskov \& Allen (1966 $a, b, c)$ and Ørskov et al. (1966) suggested that the effect of acetic acid as being as efficient as propionate or butyrate, or even more efficient, is only apparent when the animals are fed slightly above their maintenance requirement, and not with moderate levels of feeding. They concluded that the lower efficiency of utilization of diets fermented in the rumen to produce high molar proportions of acetic acid might be due to energy losses occurring during the formation of acetic acid rather than during its subsequent utilization. The results obtained by us are not in agreement with these findings. In all instances the basal rations were offered slightly above their maintenance level of $\mathrm{DE}$, permitting easy detection of the specific effect of each metabolite.

Bull, Johnson \& Reid ( 1967 ) have offered an explanation, suggesting that the high heat increment of acetic acid recorded in short-term infusion experiments is not maintained over long periods because metabolic mechanisms adapt to the increased load of acetate. Evidence for this was also presented by Jacobson, Reid \& Ulyatt (1971). 
In our studies no evidence of adaptation as reflected by changes in pattern of $\mathrm{N}$ excretion and retention after acetate infusion was observed between the $5^{\text {th }}$ day and the $9^{\text {th- }} \mathrm{I} 2$ th days of infusion. $\mathrm{N}$ retention was not measured on days $\mathrm{I}-4$ of the test periods.

Information available from tolerance studies (Reid, I958; Pfander \& Reid, I959, I960) suggests that the level of nutrition plays an important part in determining the utilization of injected acetate. The fed animal is capable of removing acetate at a much greater rate than is its fasted counterpart. These results are in agreement with respiration calorimetry studies by Armstrong \& Blaxter (1960).

The results of Armstrong \& Blaxter ( $1957 b$ ) and Armstrong $e t$ al. (1958) relating to comparative utilization of the three major $\mathrm{VFA}$ in lipogenesis are in agreement with results associated with growth obtained in the present work, that is, that acetic acid is utilized less efficiently than propionic or butyric acids in the two processes mentioned.

Intravenous infusions of the three major VFA and glucose lowered the faecal $N$ excretion in all the experiments. This effect, however, was not significant $(P>0.05)$ in all instances. Intravenous infusion of butyrate lowered the faecal $\mathrm{N}$ excretion more than infusion of any of the other energy sources in all experiments, though in most of the experiments this effect was not significantly different from that of the other energy sources. The mechanism of this action is not known and has not been previously reported. The reduced faecal $N$ excretion for butyrate treatment increased the $N$ balance for that treatment proportionally.

\section{REFERENCES}

Armstrong, D. G. \& Blaxter, K. L. (I957a). Br. F. Nutr. II, 247.

Armstrong, D. G. \& Blaxter, K. L. (1957b). Br. F. Nutr. Ix, 4I3.

Armstrong, D. G. \& Blaxter, K. L. (1960). Proc. int. Congr. Nutr. v. Wash. p. 74.

Armstrong, D. G., Blaxter, K. L., Graham, N. McC. \& Wainman, F. W. (I958). Br. F. Nutr. 12, I77.

Bentley, O. G., Johnson, R. R., Royal, G. W., Deatherage, F., Kunkle, L. E., Tyznik, W. J. \& Bell, D. S. (1956). Res. Bull. Ohio agric. Exp. Sin no. 774, p. 3 .

Bergman, E. N., Reid, R. S., Murray, M. G., Brockway, J. M. \& Whitelaw, F. G. (1965). Biochem. $\mathcal{F}$. 97,53 .

Black, A. L., Klciber, M., Smith, A. H. \& Stewart, D. N. (1957). Biochim. biophys. Acta $23,54$.

Bull, L. S., Johnson, D. E. \& Reid, J. T. (1967). Proc. Cornell Nutr. Conf. Feed Mfrs p. 83 .

Elliot, J. M., Hogue, D. E., Myers, G. S. Jr \& Loosli, J. K. (1965). F. Nutr. 87, 233.

Essig, H. W., Hattield, E. E. \& Johnson, B. C. (1959). F. Nutr. 69, I35.

Hoveil, F. D. (1964). Anim. Prod. 6, 26r.

Jacobson, D. R., Reid, C. S. W. \& Ulyatt, M. J. (1971). Fedn Proc. Fedn Am. Socs exp. Biol. 30, 295 Abs. Leng, R. A. \& Brett, D. J. (I966), Br. F. Nutr. 20, 54I.

Orskov, E. R. \& Allen, D. M. (1966a). Br. Y. Nutr. 20, 295.

Orskov, E. R. \& Allen, D. M. (1966b). Br. F. Nutr. 20, 509.

Orskov, E. R. \& Allen, D. M. (1966c). Br. $\mathcal{F}$. Nutr. 20, 5 I 9.

Orskov, E. R., Hovell, F. D. \& Allen, D. M. (I966). Br. F. Nutr. 20, 307.

Pfander, W. H. \& Phillipson, A. T. (1953). \%. Physiol., Lond. 122, 102.

Pfander, W. H. \& Reid, R. L. (1959). F. Anim. Sci. 18, 1560.

Pfander, W. H. \& Reid, R. I. (r960). Fedn Proc. Fedn Am. Socs exp. Biol. r9, 323.

Potter, E. L., Purser, D. B. \& Cline, J. H. (r968). J. Nutr. 95, 655.

Reid, R. L. (1958). Aust. 7. agric. Res. 9, 788 .

Rook, J. A. F., Balch, C. C., Campling, R. C. \& Fisher, L. J. (1963). Br. F. Nutr. I7, 399.

Thomson, D. J. (1965). Proc. Nutr. Soc, 24, xxvi.

Van Soest, P. J. (1967). J. Anim. Sci. 26, 119. 